\title{
FILOSOFI SISTEM KEKERABATAN MATRILINEAL SEBAGAI PERLINDUNGAN SOSIAL KELUARGA PADA MASYARAKAT MINANGKABAU
}

\author{
Ellies Sukmawati \\ UIN Syarif Hidayatullah Jakarta \\ Email: ellies.sukmawati@uinjkt.ac.id
}

\begin{abstract}
Minangkabau is one of the tribes in Indonesia using matrilineal as a kinship system in which the formation of lineage is arranged according to the female line. The Minangkabau kinship system uses a "Gadang" house as its symbol. The inheritance inherited by the family in the form of a "Gadang" house and assets in agriculture and fisheries to be managed and utilized together by one family (a "paruik"). Every female lineage in the family has the right to live in a "Gadang" house and their children are raised on funding from inheritance. The shared responsibility (communal) in the Minangkabau matrilineal system is seen in the supervision model applied in it, where the task of supervising and educating children in the matrilineal family is the mother and her mother's brothers (mamak), as well as adults others inside the "Gadang" house. This study combines social protection systems with the philosophy of the Minangkabau matrilineal kinship system which can play a role in protecting the community from social problems that can disrupt the stability of the welfare of a family. But over time this matrilineal system has faded, but the symbols of the system of Gadang house can still be seen in the Minangkabau community, including those who have migrated and settled outside West Sumatra.
\end{abstract}

Keywords: Matrilineal kinship system, the system of "Gadang" house, inheritance and the role of men (mamak).

\begin{abstract}
Abstrak. Minangkabau merupakan salah satu suku di Indonesia mempergunakan matrilineal sebagai sistem kekerabatannya di mana pembentukan garis keturunan diatur menurut garis perempuan. Sistem kekerabatan Minangkabau mempergunakan rumah gadang sebagai simbolnya. Harta pusaka yang diwariskan oleh keluarga berupa rumah gadang dan aset di bidang pertanian maupun perikanan untuk dikelola dan dimanfaatkan secara bersama oleh satu keluarga (sabuah paruik). Setiap keturunan perempuan dalam keluarga berhak untuk menghuni rumah gadang dan anak-anak mereka dibesarkan dengan pembiayaan dari harta pusaka. Tanggung jawab bersama (communal) di dalam sistem matrilineal Minangkabau terlihat pada model pengawasan yang diterapkan di dalamnya, di mana yang bertugas mengawasi dan mendidik anak-anak dalam keluarga matrilineal adalah ibu dan saudara laki-laki ibunya (mamak), serta orang-orang dewasa lainnya di dalam rumah gadang. Penelitian ini menggabungkan sistem perlindungan sosial dengan filofosi sistem kekerabatan matrilineal Minangkabau yang dapat berperan untuk memproteksi masyarakat dari permasalahan sosial yang dapat mengganggu stabilitas kesejahteraan suatu keluarga. Namun seiring waktu sistem matrilineal ini telah semakin memudar, namun simbol-simbol sistem rumah gadang masih dapat terlihat pada masyarakat Minangkabau, termasuk dengan mereka yang telah merantau dan menetap di luar Sumatera Barat.
\end{abstract}

Kata Kunci: Sistem kekerabatan matrilineal, sistem rumah gadang, harta pusaka dan peran laki-laki (mamak). 


\section{Pendahuluan}

Secara teoritis keluarga itu dapat dilihat dari dua segi yaitu keluarga inti (Nuclear Family) dan keluarga luas (Extended Family). Keluarga inti terdiri dari suami, istri dan anak-anaknya. Sedangkan keluarga luas melingkupi keluarga inti ditambah dengan nenek, kakek, paman, adik dan lain sebagainya. Keluarga dianggap tidak utuh bila salah satu unsur dari keluarga inti tidak terdapat dalam keluarga tersebut. Sebab unsur-unsur tersebut memiliki fungsinya masingmasing yang saling terkait. Misalnya, suami merupakan sentral dari keluarga yang berfungsi sebagai pencari nafkah dan penanggung jawab umum dalam keluarga, sedangkan istri adalah sebagai pengendali dalam pelayanan anggota rumah tangga. Seorang suami merupakan tulang punggung keluarga yang bertanggung jawab terhadap nafkah, perlindungan, pendidikan, keamanan dan kesejahteraan anggota keluarganya. Sedangkan istri bertanggung jawab terhadap penyediaan makan minum, membimbing belajar, mencuci pakaian, memasak dan lain sebagainya.

Kehilangan salah satu di antara suami atau istri dalam keluarga akan mengguncang keutuhan, kerukunan, dan kesejahteraan keluarga tersebut. Terlebih jika yang meninggalkan keluarga adalah suami, baik karena meninggal ataupun karena hal lainnya. Faktor ekonomi rumah tangga adalah yang paling rentan untuk terganggu jika kehilangan suami sebagai tulang punggung keluarga. Sang istri akan menggantikan perannya. Sehingga selain sebagai pengasuh anakanaknya, sang istri juga akan berfungsi sebagai pencari nafkah. Ini tidak mudah karena kemampuan seorang suami berbeda dengan kemampuan seorang istri, sehingga jika tidak terpenuhi kebutuhan rumah tangga akan mengakibatkan ketenangan, keutuhan dan kesejahteraan keluarganya terganggu. Perangkapan fungsi tersebut akan berdampak terhadap aspek psikologis maupun sosial, seperti stress, emosional yang labil, rasa kesepian dan merasa terkucilkan dari masyarakat.

Berdasarkan kenyataan tersebut, maka pertanyaan utama adalah seberapa besar kebutuhan suatu keluarga terhadap perlindungan sosial untuk bisa melindunginya dari baragam permasalahan sosial yang diakibatkan oleh hilangnya tulang punggung dan pengayom keluarga. Menurut Sanusi, perlindungan sosial merupakan perangkat kebijakan dan program yang dirancang untuk mengurangi kemiskinan dan kerentanan dengan meningkatkan lapangan kerja, mengurangi kelompok penduduk yang beresiko tinggi serta 


\section{Filosofi Sistem Kekerabatan Matrilineal sebagai Perlindungan \\ Sosial Keluarga pada Masyarakat Minangkabau \\ - Ellies Sukmawati}

meningkatkan kemampuan mereka untuk melindungi diri sendiri dari bahaya dan hilangnya penghasilan (Badan Pelatihan dan Pengembangan Sosial, 2004). Di Indonesia perlindungan sosial dapat berbentuk formal yang merupakan program pemerintah, serta ada juga yang berbentuk informal yang berasal dari budaya lokal masyarakat Indonesia, hal ini setidaknya bila mengacu kepada pendapat Suharto (2008) yang menyatakan bahwa perlindungan sosial merupakan praktik-praktik informal seperti arisan, sistem gotong royong, dukungan keluarga atau teman atau skema jaring pengaman sosial yang berbasis masyarakat.

\section{Metode}

Pendekatan yang digunakan dalam penelitian ini adalah Kualitatif, dengan pendekatan analisis deskriptif. Membahas praktik perlindungan sosial informal memiliki kebermanfaatan tersendiri, di mana Indonesia adalah negara yang kaya dengan budaya, dan melahirkan beragam kearifan lokal di masyarakat, sehingga dapat dijadikan sebagai modal bagi pembangunan perlindungan sosial di Indonesia, baik dalam bentuk bantuan sosial maupun asuransi sosial. Salah satu bentuk praktiknya melalui sistem kekerabatan matrilineal yang ada pada masyarakat Minangkabau. Zurinal (2001) menyebut keluarga atau rumah tangga merupakan bagian terkecil dari suatu organisasi, karena itu setiap anggota keluarga merupakan sub-sistem dari suatu sistem kekerabatan yang berkembang dalam masyarakat. Masyarakat Minangkabau, di bawah sistem matrilineal, hidup di dalam satu ketertiban masyarakat yang di dalamnya kekerabatan dihitung menurut garis ibu dan pusaka serta warisan diturunkan menurut garis ibu pula, ini artinya anak laki-laki dan perempuan termasuk keluarga, klan dan perkauman ibunya, yang menerima warisan harta-benda (Radjab, 1969).

Representasi dari identitas masyarakat Minangkabau pada sistem matrilineal adalah rumah gadang yang mumnya didiami oleh tiga generasi, yakni terdiri dari beberapa anak perempuan dan anak laki-laki, ibu mereka dan saudara laki-laki dari ibu mereka (mamak), saudara-saudara perempuan dari ibu mereka (incu) dengan anak-anaknya, ibu dari ibu (nenek) mereka dengan anak-anaknya pula, anak-anak dari anak perempuan incu-incu mereka dan saudara laki-laki dari nenek mereka, dan lain-lainnya (Badan Pelatihan dan Pengembangan Sosial, 2004). Pada sistem rumah gadang ada pola pengawasan 
langsung oleh penghulu suku terhadap keponakan-keponakannya baik lakilaki maupun perempuan. Diketahui pula penghulu-penghulu sukulah yang memegang kekuasaan atas tanah dan harta-benda komunal dari suku, dan mempunyai kewajiban memberi makan, pakaian dan perlindungan kepada anggota-anggota kelompok sukunya. Pada masa itu kemenakan-kemenakannya yang perempuan tidak menuntut nafkah hidup dari suami mereka, dan cucucucu mereka tidak mengharapkan jaminan hidup pula dari ayahnya. Suatu kebaikan lagi dari rumah gadang itu adalah jika seorang isteri diceraikan oleh suaminya, atau anak-anak menjadi piatu karena kedua orang tuanya meninggal, penghidupan mereka dijamin oleh mamak rumah, yang memegang kekuasaan atas harta benda komunal untuk kesejahteraan angota kelompoknya.

Bila mengacu kepada paparan di atas, ternyata sistem kekerabatan yang berkembang dalam masyarakat merupakan unsur perlindungan sosial yang tidak dapat diabaikan, apalagi bagi masyarakat Minangkabau yang secara kokoh menganut sistem kekerabatan matrilineal, di mana garis keturunan dihitung menurut garis keturunan ibu (wanita) dan sistem kekerabatan ini telah menempatkan posisi wanita pada posisi yang sangat sentral, sebagai penguasa harta pusaka yang dapat dijadikan jaminan sosial dan pelindung dari berbagai permasalahan ekonomi rumah tangga yang dihadapi oleh anggota keluarganya.

Berdasarkan pandangan di atas, maka menjadi sangat penting untuk dilakukannya penelitian tentang sistem kekerabatan matrilineal, dan melalui literature review dari beberapa tulisan sistem kekerabatan matrilineal masyarakat Minangkabau dapat tergambarkan aspek-aspek sistem kekerabatan yang berperan perlindungan sosial untuk melindungi kesejahteraan keluarga pada masyarakat Minangkabau, khususnya pada sistem rumah gadang yang mengatur peran harta warisan keluarga dan peran saudara laki-laki terhadap pembiayaan pembiayaan pendidikan dan kebutuhan lainnya bagi anakanak dalam suatu keluarga. Selain itu, penelitian ini juga bertujuan melihat keberadaan sistem kekerabatan matrilineal saat ini serta kendala-kendala yang dapat mengurangi efektifitas dari sistem kekerabatan matrilineal saat ini dalam memberikan perlindungan sosial terhadap keluarga pada masyarakat Minangkabau. 


\section{Hasil dan Diskusi}

\section{Kajian Terhadap Rumah Gadang dalam Sistem Matrilineal Minangkabau}

Sistem kekerabatan matrilineal di Sumatera Barat merupakan bagian dari adat istiadat Minangkabau sekaligus merupakan suatu sistem yang masih dijalankan di kalangan suku Minangkabau baik itu yang berdomisili di Sumatera Barat maupun yang sudah merantau ke luar dari Sumatera. Sistem matrilineal pada masyarakat Minangkabau adalah sistem kekerabatan yang mengikuti garis ibu, sehingga keturunan diatur menurut garis ibu (Kato, 1982; Stark, 2013; Radjab, 1969). Radjab (1969) menyebut ada delapan ciri yang menggambarkan sistem matrilineal pada masyarakat Minangkabau, yakni: 1) keturunan dihitung menurut garis ibu; 2) suku terbentuk menurut garis ibu; 3) tiap orang diharuskan kawin dengan orang luar sukunya; 4) pembalasan dendam merupakan satu kewajiban bagi seluruh sukunya; 5) kekuasaan di dalam suku, menurut teori terletak di tangan ibu, walaupun jarang sekali dipergunakan; 6) yang sebenarnya berkuasa adalah saudara laki-laki; 7) perkawinan bersifat matrilokal, yaitu suami mengunjungi rumah isterinya; 8) hak-hak dan pusaka diwariskan oleh mamak kepada kemenakannya, dari saudara laki-laki ibu kepada anak dari saudara perempuan.

Mengaitkan sistem matrilineal dengan perlindungan sosial, maka perlu untuk memahami terlabih dahulu bagaimanakah sistem rumah gadang dalam menggerakkan berbagai komponen di dalamnya untuk saling terkait membentuk skema perlindungan sosial. Banyak peneliti yang tertarik pada keberadaan rumah gadang. Elda Franzia, dkk (2015) menyebut bahwa rumah gadang adalah rumah besar berbentuk persegi panjang besar dengan atap bertingkat yang dikenal dengan bagonjong, merupakan rumah tradisional Minangkabau, di mana arsitektur, konstruksi, dekorasi internal dan eksternal, dan fungsi rumah mencerminkan budaya dan nilai-nilai suku Minangkabau. Dia juga menyebut rumah gadang berfungsi sebagai tempat tinggal, aula untuk pertemuan keluarga, dan untuk kegiatan seremonial. Itu dimiliki oleh wanita dari keluarga yang tinggal di sana, dan kepemilikannya diturunkan dari ibu ke anak perempuan.

Radjab (1969, h. 24-25) menjelaskan keberadaan rumah gadang pada masyarakat Minangkabau: 
Rumah gadang itu umumnya didiami oleh tiga generasi, biasanya dapat berjumlah antara 30-50 orang. Satuan genealogis yang mendiami rumah gadang dikenal dengan istilah sabuah paru,', yang artinya keluar dari satu kandungan oleh seorang nenek. Sabuah paru' terdiri dari beberapa samande yang merupakan saudara seibu. Setiap satuan genealogis ini dipimpin dan diawasi oleh seorang datuk atau mamak disebut sebagai "kapalo parui".

Lebih lanjut, Radjab (1969, h. 24-25) juga menyebut mengenai ukuran maupun jumlah rumah gadang yang dimiliki oleh setiap keluarga dapat bertambah seiring dengan betambahnya jumlah penghuni rumah gadang:

Jika rumah gadang bersama itu mulai sempit karena penghuninya bertambah, maka didirikan sebuah rumah gadang baru untuk anak-anak perempuan. Rumah gadang baru didirikan di dekat yang lama, di atas kepunyaan komunal, atau bisa juga ditanah kampung lain, tetapi rumah baru dan penghuninya masih terhitung dari lingkungan kampung atau suku asli. Sekelompok dari anggota sabuah paru'atau samande menjadi penghuni rumah baru tersebut, dibawah pengawasan penghulu yang lama atau bisa juga mengangkat penghulu yang baru.

Dengan adanya keberadaan rumah gadang untuk keluarga, maka tidak ada anggota keluarga yang terlantar karena tidak memiliki rumah. Rumah gadang memiliki beberapa aturan bagi penghuninya. (Muhammad Radjab, 1969, h. 28) berikut ini:

Berhubung dengan adanya pertalian darah yang rapat, maka tiap-tiap orang di dalam sebuah rumah gadang mempunyai hak dan kewajiban terhadap anggota lainnya. Di dalam rumah gadang anak-anak diajarkan oleh orangorang dewasa bahwa mereka semua satu keluarga, harus tolong menolong, bantu membantu saling mencintai (Radjab, 1969, h. 28).

Pada sistem rumah gadang ada aturan yang mengatur pengelolaan harta warisan keluarga (sabuah paru). Sistem matrilineal Minangkabau memiliki aturan tersendiri dalam pengelolaan harta yang diwariskan kepada keturunannya. Tanah yang "diperoleh" melalui warisan adalah harta pusaka (properti akestral) yang diperoleh melalui garis ibu (Kato, 1982), dengan memberikan kepada tiap orang yang berhak atas sebidang sawah, tanah, kebun atau ladang dari harta pusaka, untuk dipergunakan oleh kemenakannya tersebut [4, pp. 57-58]. Ini berarti bahwa anak laki-laki dan perempuan termasuk keluarga, klan dan perkauman ibunya, dan bukan dari ayah melainkan dari ibu, mamak dan bibinya seorang anak menerima warisan harta-benda (Radjab, 


\section{Filosofi Sistem Kekerabatan Matrilineal sebagai Perlindungan \\ Sosial Keluarga pada Masyarakat Minangkabau \\ - Ellies Sukmawati}

1969). Tanah pusaka yang diwarisi secara turun temurun ini akhirnya dimiliki secara bersama oleh seluruh anggota suku dan kaum di mana oleh sistem adat tidak boleh dijual dan digadaikan kecuali dengan persetujuan keluarga yang harus didasarkan kepada 3 hal yaitu jika tidak memiliki biaya untuk pemakaman anggota keluarga, tidak memiliki biaya untuk menikahkan anak perempuannya dan tidak memiliki biaya untuk memperbaiki rumah gadang yang rusak (Hanifuddin, 2011). Selain itu, pemindahan kepemilikan harta pusaka pun harus dilakukan ke payung terdekat dalam suku yang sama (Kato, 1982). Lahan pertanian yang dimiliki keluarga bersifat komunal maka pemanfaatannya juga bersifat komunal. Menurut Radjab (1969) lahan-lahan yang diperuntukkan itu harus dikerjakan dan ditanami sendiri oleh perempuan-perempuan itu dengan dibantu oleh saudara laki-lakinya dan kemudian oleh anak laki-lakinya jika sudah dewasa, suaminya boleh membantunya, tetapi tidak diwajibkan oleh adat, sebab menurut adat ia diwajibkan bekerja untuk saudara perempuan dan kemenakannya. Namun bagi laki-laki yang memperoleh sebidang tanah pusaka dari mamaknya untuk ditanaminya, hanya boleh memberikan sebagian saja dari hasil bercocok tanam untuk isteri dan anak-anaknya, selebihnya diberikan untuk saudara perempuannya. Dalam pelaksanaan sehari-hari, sistem matrilineal menempatkan posisi yang seimbang antara laki-laki dan perempuan (Hanifuddin, 2011). Perempuan ialah pemilik harta yang berperan sosial secara mendalam, sedangkan laki-laki pemimpin yang berperan politik secara luaran (Julius Dt. Malako Nan Putiah, 2007)

Menurut Sutan Mangkuto (dalam Kato, 1982) harta pusaka berfungsi untuk mendukung kehidupan di rumah gadang, sehingga anggota rumah yang sama mengolah tanah pertanian yang diberikan kepada mereka secara bersama, selanjutnya beras yang dihasilkan disimpan dalam 3 lumbung, yaitu satu untuk penggunaan sehari-hari anggota rumah, satu untuk memberi makan tamu dan orang yang lewat, dan satu lagi untuk upacara dan keperluan khusus.

Ada beberapa hal yang melatarbelakangi masyarakat Minangkabau menerapkan prinsip komunal dalam pemanfaatan harta pusakanya. Hanifuddin (2011) mengatakan bahwa hakekat pemusakaan tanah ulayat secara komunal dan turun temurun ini adalah untuk menghalangi terjadinya pemilikan oleh individu untuk memberi kesempatan kepada sesama anggota masyarakat dan generasi masa depan supaya turut memperoleh kesejahteraan dari aspek tanah, dan hal ini disebabkan oleh: 1) secara geoekonomi, Sumatera Barat merupakan 
propinsi yang mempunyai aset ekonomi paling sedikit, baik dari dalam bumi maupun dari permukaan tanahnya; dan 2) secara topografi, tanah di sini dapat dianggap sempit karena permukaan tanahnya dipenuhi oleh lembah, perbukitan, dan jalan berliku.

Selain mengatur pengelolaan harta pusaka keluarga (sabuah paru), rumah gadang juga mengatur fungsi maupun peran dari laki-laki dalam rumah gadang, dalam hal ini adalah saudara laki-laki dari perempuan maupun paman yang ada dalam sabuah paru yang dikenal dengan istilah mamak. Kakak laki-laki perempuanlah yang bertanggung jawab atas anak-anaknya daripada suaminya sendiri (Stark, 2013). Dijelaskan oleh [9, p. 280] mamak merupakan pusat dan inti dari sistem kekerabatan matrilineal dan rumah gadang sebagai basis tempat tinggal anggota secara luas. Di dalam rumah gadang inilah eksistensi mamak akan diakui oleh seluruh anggota keluarga, dengan mempunyai tanggungjawab sebagai pemelihara dan pemberi kesejahteraan kepada anggota rumah gadang tersebut, sehingga semua aktivitas yang berhubungan dengan rumah gadang akan selalu melibatkan mamak.

Esensi matrilineal Minangkabau terutama terkonsentrasi dalam hubungan dua generasi mamak dan dan kemenakan (keponakan), sehingga kewajiban dan tugas timbal balik dari mamak dan kemenakan diatur oleh adat, di mana mamak sebagai penjaga kemenakan dan bertanggung jawab atas kesejahteraan kemenakan yang akan melanjutkan garis keturunan mereka, sehingga mamak diberkahi dengan otoritas sebagai tungganai atau penghulu, dan diharapkan untuk melindungi dan meningkatkan harta pusaka (Kato, 1982). Lebih lanjut dijelaskan oleh Radjab (1969), kepala rumah tangga adalah mamak, bukan ayah dari anak-anaknya, dan kewajiban seorang mamak terhadap kemenakannya terutama yang perempuan adalah memberi makan, pakaian, rumah, dll, bahkan jika sabuah parui' atau djurai mempunyai sedikit tanah untuk dijadikan sawah atau kebun yang hasilnya hanya cukup untuk dimakan bersama-sama, maka tiap laki-laki dewasa di keluarga diajarkan pergi berdagang keluar nagarinya atau pergi merantau, dan penghasilan kerjanya dirantau dapat dipergunakan untuk membantu saudara-saudara perempuan serta kemenakan-kemenakannya, biasanya dengan mengirimkan sejumlah uang tiap bulan, bahan pakaian, perhiasan dan sebagainya. 


\section{Filosofi Sistem Kekerabatan Matrilineal terhadap Perlindungan Sosial Keluarga pada Masyarakat Minangkabau}

Kesejahteraan keluarga dipengaruhi oleh kondisi ekonomi yang dapat membentuk ketahanan keluarga dalam pemenuhan kebutuhan keluarga, sehingga jika suatu keluarga mengalami ketidakmampuan dalam hal ekonomi dapat mengakibatkan suatu keluarga mengalami kondisi kemiskinan. Untuk itu diperlukan upaya untuk dapat melindungi kekuatan ekonomi suatu keluarga agar terhindar dari kemiskinan. Menurut Suharto (2008), perlindungan sosial merupakan sarana penting untuk meringankan dampak kemiskinan dan kemelaratan yang dihadapi kelompok miskin beserta anak-anak mereka. Sanusi menyebut bahwa skema perlindungan sosial didasarkan pada 4 komponen utama, yaitu lapangan pekerjaan, jaminan sosial, asuransi sosial dan pola perlindungan berbasis lokal, (Badan Pelatihan dan Pengembangan Sosial Kementerian Sosial, 2004). Dan keberadaan tradisi lokal berfungsi sebagai mekanisme efektif untuk mempertahankan laju pertumbuhan perlindungan sosial pada tingkat nasional (Suharto, 2008). Jaminan sosial diimplementasikan ke dalam berbagai bentuk tunjangan pendapatan secara langsung ... kerap meliputi pula berbagai skema peningkatan akses terhadap pelayanan sosial dasar seperti perawatan kesehatan, pendidikan, dan perumahan (Suharto, 2008). Hal inilah yang dilihat implementasinya pada filosofi sistem kekerabatan matrilineal pada masyarakat minangkabau.

Terdapat beberapa komponen utama pada sistem kekerabatan matrilineal yang memiliki kesamaan dengan skema perlindungunan sosial di bidang pertanian dan sektor informal di perkotaan, terutama sistem rumah gadang, pengelolaan harta pusaka keluarga (sabuah paru) dan peranan mamak terhadap para kemenakannya.

Keberadaan rumah gadang dapat dihubungkan dengan perspektif jaminan sosial berbasis kekerabatan yang disebutkan oleh Suharto (2008) di mana fungsi utama skema jaminan kesejahteraan sosial berbasis masyarakat untuk mempertahankan keberlanjutan kesejahteraan kehidupan bagi keluarga di pedesaan mempergunakan mekanisme informal untuk menghadapi kesulitan dalam kehidupan sehari-hari melalui dukungan dan bantuan dari kerabat. Fungsi rumah gadang sebagai rumah bersama terhadap beberapa keluarga dari 2-3 generasi, sehingga bisa menampung puluhan orang. Rumah gadang ini dapat bertambah jumlahnya pada suatu keluarga (sabuah paru) seiring dengan 
bertambahnya jumlah anggota keluarga yang akan menikah. Hal ini dapat menjadi suatu bentuk pelindungan yang diberikan oleh sistem kekerabatan untuk melindungi anggota keluarga dari ketidakmampuan memiliki tempat tinggal bahkan juga ketelantaran.

Demikian pula halnya dengan pengelolaan harta warisan atau yang dikenal dengan harta pusaka yang diberikan kepada keturunan dan garis ibu, dengan ketentuan tidak untuk dimiliki oleh individu melainkan kepemilikan komunal, sehingga pemanfaatannya pun bersifat komunal. Sistem ini dapat dihubungkan dengan pola perlindungan berbasis lokal, sebagai suatu program yang ditujukan untuk menghadapi rintangan-rintangan pembangunan ekonomi di pedesaan (Badan Pelatihan dan Pengembangan Sosial Kementerian Sosial, 2004). Secara geoekonomi dan topografi Sumatera Barat memiliki keterbatasan sumberdaya alam untuk mendukung perekonomian sesuai dengan pertumbuhan jumlah penduduknya. Dengan kedua keterbatasan ini tidak dapat dibayangkan seandainya aset tanah yang sempit dan sedikit nilai ekonominya ini dikuasai oleh beberapa individu saja melalui pemilikan pribadi. Sehingga pengelolaan secara komunal dapat dijadikan sebagai alat untuk memastikan setiap individu akan selalu memiliki aset ekonomi dan memiliki pekerjaan dengan mengelola aset keluarga. Terlebih lagi sistem kekerabatan matrilineal menempatkan wanita sebagai pengelola harta pusaka, mereka tidak tergantung kepada suami sebagai tulang punggung keluarga, sehingga pola-pola pemberdayaan wanita di bidang ekonomi terlihat kental pada sistem matrilineal.

Suharto (2008) menyebutkan terdapat 4 bentuk jaminan kesejahteraan berbasis masyarakat yaitu asuransi mikro, asuransi pertanian, dana/tunjangan sosial yang mengedepankan modal sosial, dan persiapan bencana lokal. Pada masyarakat minangkabau, setidaknya dua bentuk jaminan kesejahteraan berbasis masyarakat yaitu asuransi mikro dan dana/tunjangan sosial yang mengedepankan modal sosial, telah menjadi bagian dalam sistem kekerabatan matrilineal.

Pola jaminan kesejahteraan sosial berbasis masyarakat berupa asuransi mikro yang dikelola secara lokal, dapat terlihat pada sistem kekerabatan matrilineal yang menyediakan lahan pertanian melalui harta pusaka tinggi maupun rendah kepada keturunannya, sehingga setiap keturunan keluarga (sabuah paru) memiliki modal fisik sekaligus finansial, dengan memiliki tempat tinggal dan mata pencaharian melalui pengelolaan aset harta pusaka, di mana 


\section{Filosofi Sistem Kekerabatan Matrilineal sebagai Perlindungan \\ Sosial Keluarga pada Masyarakat Minangkabau \\ - Ellies Sukmawati}

mereka dapat mengelolanya dan menghidupi keluarganya dari hasil lahan pertanian, perikanan, dan lain-lain, serta kebutuhan setiap keluarga dalam ikatan (sabuah paru) akan dipenuhi secara bergotong royong. Terlebih dengan adanya aturan bahwa harta pusaka tidak boleh diperjualbelikan, kecuali sesuai dengan alasan yang telah ditentukan oleh sistem matrilineal, secara tidak langsung dapat menjaga keberlanjutan kepemilikan mereka akan asset keluarga. Berdasarkan hal ini maka sistem kekerabatan matrilineal telah memberikan pilihan kepada masyarakat untuk melindungi anggota kelompok dari resiko ekonomi yang mungkin terjadi yaitu mencegah mereka dari kehilangan mata pencaharian. Lebih lanjut konsep modal sosial menjadi landasan dalam pengelolaan harta pusaka oleh pihak laki-laki maupun perempuan pada suku minangkabau. Hal ini dapat dilihat dari ketentuan seorang suami dapat mengelola lahan pertanian (harta pusaka keluarga) namun keuntungannya tidak boleh diberikan kepada anak maupun isterinya, karena keuntungan dari lahan pertanian harta pusaka wajib diberikan kepada para kakak/adik perempuan maupun kemenakannya. Ketentuan ini dapat berjalan dengan adanya kepercayaan dari kakak/adik perempuan maupun kemenakan kepada para mamak yang mengelola harta pusaka. Sedangkan para mamak yang sekaligus suami juga mempercayai bahwa kebutuhan anak-anak maupun isterinya juga telah dipenuhi oleh harta pusaka matrilineal keluarga isterinya. Berdasarkan hal ini terlihat ada kepercayaan dan kerjasama dalam setiap keluarga matrilineal untuk memenuhi kebutuhan akan pekerjaan, perumahan, pendidikan, dan lain sebagainya, yang ditujukan kepada keturunannya.

Skema jaminan kesejahteraan sosial berupa dana/tunjangan terlihat pada pemanfaatan harta pusaka di mana anak-anak keturunan (sabuah paru) dibesarkan oleh harta pusaka matrilinealnya. Terlebih lagi adanya peran mamak yang bertanggung jawab dan bertugas melindungi para kemenakan yang merupakan anak-anak dari saudara perempuannya. Para kemenakan ini akan menjadi penerus garis keturunan (khususnya perempuan), sehingga mamak berkewajiban untuk melindungi dan meningkatkan jumlah harta pusaka keluarga, agar dapat membiayai dan memenuhi kebutuhan keturunan keluarganya baik biaya sekolah, pakaian, kesehatan maupun rumah. Jika harta pusaka keluarga tidak cukup, maka setiap laki-laki dewasa di keluarga diajarkan pergi merantau untuk berdagang. Penghasilannya dirantau sebagian dipergunakan untuk membantu saudara-saudara perempuan serta kemenakan- 
kemenakannya, biasanya dengan mengirimkan sejumlah uang tiap bulan, bahan pakaian, perhiasan dan sebagainya. Terkait dengan ketersediaan daya tampung rumah gadang, para mamak dalam (sabuah paru) berkewajiban untuk memperluas rumah gadang bahkan membangun rumah gadang baru, jika daya tampung rumah gadang telah berkurang. Pembiayaan perluasan maupun pembangunan rumah gadang baru diperoleh dari keuntungan pengelolaan harta pusaka dan kiriman uang dari para mamak yang bekerja di perantauan.

\section{Perubahan Sosial pada Sistem Kekerabatan Matrilineal}

Perubahan sosial pada sistem kekerabatan matrilineal Minangkabau telah banyak dilakukan oleh para peneliti. Seperti kajian perpindahan masyarakat suku Minangkabau ke daerah lain (merantau) secara tidak langsung membuat hubungan kekeluargaan yang erat dengan keluarganya menjadi berkurang, khususnya peranan dan wewenang mamak dalam sistem kekerabatan matrilineal yang semakin memudar seiring berjalannya waktu. Secara fisik mereka akan jauh dari sanak saudaranya yang berada di kampong halaman sehingga mereka akan mengalami kesukaran untuk mengontrol keluarga maupun harta pusakanya, dan pada akhirnya tanggung jawab terhadap kemenakan dan kerabatnya baik secara moral maupun ekonomipun menjadi berkurang (Fatimah, 2008).

Pergeseran terhadap tempat tinggal juga dialami oleh masyarakat Minangkabau. Sebelum 1970-an, rumah gadang adalah tempat tinggal komunal yang dapat menampung puluhan orang, namun saat ini perlahan-lahan mereka tidak lagi tinggal dalam bentuk kelompokparuiktetapi dalam bentuk keluarga inti (Syahrizal \& Meiyenti, 2012). Semakin meningkatnya pertumbuhan penduduk juga berdampak terhadap kemampuan harta pusaka dalam memberikan manfaat kepada anggota keluarganya, karena setiap tahunnya anggota keluarga bertambah sementara jumlah harta pusaka tinggi tidak, sehingga akhirnya rumah gadang tidak mampu menampung penghuninya dan hasil pertanian tidak lagi mencukupi kebutuhan hidup suatu keluarga (Syahrizal \& Meiyenti, 2012). Hal ini kemudian berdampak kepada bergesernya budaya matrilineal juga berakibat tanggung jawab para mamak/paman juga semakin berkurang kepada para keponakannya karena yang lebih dominan adalah orang tuanya masingmasing, sehingga budaya individualis semakin kuat, dan kalau pun mamak/ paman berperan terhadap kemenakannya, itu sifatnya sebagai pertolongan biasa. Modernisasi juga berdampak pada perubahan dalam sistem pembagian 


\section{Filosofi Sistem Kekerabatan Matrilineal sebagai Perlindungan \\ Sosial Keluarga pada Masyarakat Minangkabau \\ - Ellies Sukmawati}

warisan, dahulunya memakai sistem kekerabatan matrilineal namun lambat laun harta-harta pusaka rendah atau harta gono gini suatu keluarga hanya akan dibagi menurut hukum islam untuk anak-anaknya saja. Berdasarkan hasil wawancara dengan beberapa informan adanya perpindahan masyarakat karena merantau ini juga akan mengakibatkan transfer pengetahuan budaya kepada generasi mudanya menjadi terhambat atau bahkan semakin menghilang, sehingga mengakibatkan ketidaktahuan generasi mudanya akan budaya daerah asalnya.

Perubahan-perubahan ini berdampak terhadap eksistensi kemampuan sistem matrilineal memberikan perlindungan kepada keturunanya, di mana ketahanan keluarga hanya bergantung kepada kemampuan keluarga inti saja.

Dari berbagai perubahan sosial yang telah terjadi, ada satu hal yang masih cukup kuat berdiri pada sistem kekerabatan matrilineal saat ini, yaitu mengenai harta pusaka. Syahrizal \& Meiyenti (2012) menyebut bahwa pembagian harta warisan yang menggabungkan antara hukum islam dan adat, sebagai contoh orangtua membeli sebidang tanah dan membangun sebuah rumah, selanjutnya rumah tersebut diwariskan dan menjadi milik bersama anak-anak perempuan. Dengan demikian aturan pada harta warisan menjadi harta pusaka keluarga dapat terus dipelihara. Sesuai ketentuan sistem matrilineal harta pusaka rendah yang berasal dari warisan orangtua, berupa rumah, sawah dan ladang dapat dipelihara dan dipertahankan sampai dengan generasi berikutnya maka harta pusaka rendah tersebut dapat menjadi harta pusaka tinggi bagi generasi termuda, sehingga jumlah harta pusaka tinggi setiap generasi akan selalu bertambah.

\section{Kesimpulan}

Skema perlindungan sosial yang terdiri dari 4 komponen yaitu lapangan pekerjaan, jaminan sosial, asuranasi sosial dan pola perlindungan berbasis lokal dapat terlihat pada filosofi sistem kekerabatan matrilineal melalui gambaran sistem rumah gadang yang terdiri dari garis keturunan, harta pusaka dan peranan mamak didalam keluarga matrilineal. Sebagai sistem keluarga di mana garis keturunan ditentukan garis ibu, sistem ini juga mengatur kaum wanita di Minangkabau memiliki hak penuh untuk menguasai harta pusaka keluarganya, sementara pihak laki-lakinya berperan untuk memimpin keluarga besarnya dan 
mengelola harta pusaka (lahan pertanian, perikanan, kebun, dan lain-lain), di mana hasilnya diserahkan untuk menghidupi keluarga saudara perempuannya.

Melalui sistem matrilineal, setiap perempuan keluarga matrilineal dapat memiliki lapangan pekerjaan karena ada aset keluarga yang diwariskan, dapat memiliki tempat tinggal dalam rumah gadang, bahkan pihak laki-laki yang disebut mamak/paman bertanggung jawab untuk membiayai kebutuhan (pakaian, makanan, sekolah dan rumah) serta membimbing anak-anak dari saudara perempuan (kemenakan), sehingga dalam sistem kekerabatan ini kaum wanita dan anak-anaknya sangat dilindungi dari resiko ekonomi. Hal ini dikarenakan pemenuhan kebutuhan rumah tangga tidak hanya menjadi tanggung jawab suami saja, melainkan terdapat dukungan dari keluarga besarnya.

Begitu banyakkebaikan dalam sistem kekerabatan matrilineal minangkabau ini, sehingga diharapkan pemerintah ikut andil melalui kebijakannya untuk melestarikannya. Agar perubahan sosial yang terjadi pada sistem kekerabatan matrilineal saat ini tidak benar-benar kehilangan skema perlindungan sosial berbasis komunitas informalnya.

\section{Referensi}

Stark, A. (2013). The Matrilineal System of the Minangkabau and its Persistence Throughout History: A Structural Perspective. Southeast Asia: A Multidisciplinary Journal, 13, 1-13.

Badan Pelatihan dan Pengembangan Sosial Kementerian Sosial. (2004). Isu-Isu

Tematik Pembangunan Sosial : Konsepsi dan Strategi. Badan Pelatihan dan Pengembangan Sosial Kementerian Sosial.

Suharto, E. (2008). Kebijakan Sosial Sebagai Kebijakan Publik (Vol. 2). Alfabeta. Franzia, E., Piliang, Y.A. \& Saidi, A.I. (2015). Rumah Gadang as a Symbolic

Representation of Minangkabau Ethnic Identity. International Journal of Sience and Humanity, 5 No 1, 44-49. https://doi.org/DOI: 10.7763/ IJSSH.2015.V5.419

Hanifuddin, I. (2011). Posisi Perempuan Minangkabau dalam Sistem Ulayat Menurut Adat Matrilineal dan Syarak. Faculty of Shariah of State Institute for Islamic Studies Batusangkar, Indonesia, 10 No 2, 94-111. https://doi. org/10.1234/juris.v10i2.927

Radjab, M. (1969). Sistem Kekerabatan di Minangkabau. Padang: Center for Mi- 
nangkabau Studies.

Fatimah, S. (2008). Mencermati Perubahan Sosial Masyarakat Minangkabau melalui Novel Tamu Karya Wisran Hadi. Humaniora, 20 No. 3, 278-285.

Syahrizal, \& Meiyenti, S. (2012). Sistem Kekerabatan Minangkabau Kontemporer: Suatu Kajian Perubahan dan Keberlangsungan Sistem Kekerabatan Matrilineal Minangkabau. Prociding 4th International Conference on Indonesian Studies: Unity, Diversity, Future. Presented at the the 4th International Conference on Indonesian Studies, Bali.

Kato, T. (1982). Matriliny and Migration (Evolving Minangkabau Traditions in Indonesia). Cornell University Press.

Zurinal, Z. (2001). Peranan Wanita Dalam Pendidikan Agama anak dan Korelasinya dengan Kemampuan Beragama Anak Dalam Keluarga Matrilineal di Kenagarian Kapau Sumatera Barat. 